\title{
INFORMATION ACQUISITION AND DECISION SUPPORT FOR SUBURBAN DEER MANAGEMENT
}

\author{
G. Kent Webb, San Jose State University,g.webb@sjsu.edu
}

\begin{abstract}
A web-based decision support site for public management of deer was created from an intensive daily internet search and from targeted searches. Relying on news and other sources, information has been organized based on key decision issues. This information has also been used to build a decision support simulation using detailed demographic and other data related to deer population management. Information acquisition issues and an application of the simulation are illustrated using a case study in San Jose, California, where a deer sterilization project has reduced the population below a desired target and appears destined to result in eradication of the local deer. Trail cameras were used to gather site specific information. Previous simulation approaches lacked demographic detail and were based on very narrow geographic samples, resulting in unreliable predictions for San Jose. The simulation model presented here is being tested against a very large geographic sample of cases. An anomalous case reported at Cornell, New York, is contradicted by other results and may be a result of data issues.
\end{abstract}

Keywords: Decision Support Systems, Simulation, Knowledge Management, Data Acquisition, Web Information Systems, Trail Cameras

\section{INTRODUCTION}

In a recent article, wildlife researchers McCance, Decker, Colturi, Baydack, Siemer, Curtis and Eason (2017, page 1) conclude that "urban wildlife management ranks with species imperilment as one of the greatest conservation challenges of our time" because problems with urban management could lead to a backlash against general efforts at wildlife conservation. Newspaper articles routinely report that issues related to suburban deer management are among the most divisive public decisions made in their communities. In the United States deer are legally owned by the citizens of each state so management of suburban deer is typically a community decision.

The debate among citizens about how to best manage deer is typically supported by information taken from internet searches, but the internet offers contradictory information that often confuses the public debate. Information can be difficult to find without extensive searching. Simulation models for deer population management have been constructed. However, there is no evidence from news sources reporting on the public debate, monitored as part of this research, that these models are actually used to support the decision process. One problem is that conditions may vary dramatically across locations, making it difficult to create models that can be generally applied to a variety of situations. Also, the user interfaces developed are somewhat challenging so may be too difficult for general use.

A goal of this project is to provide a website where extensive information regarding deer management is organized around key decision issues in an easy to use knowledge base. Another goal is to provide a demographically detailed simulation model that can easily incorporate local data when available. The organizational structure of the website and a summary of previous academic decision support and simulation efforts are provided in following sections of this paper. The decision process, data collection issues, and an application of the simulation model are illustrated using a case example from San Jose, California. Data issues with a case at the Cornell, New York, campus are examined as to why the results conflict with other cases and represent an unlikely simulation outcome.

\section{San Jose Case Study, A Camera Survey to Collect Information}

Figure 1 shows a photograph taken by a trail camera of a doe with an ear tag for visual identification, and a radio collar for remote monitoring - three methods of collecting information. Development of low cost, motion sensing cameras -- trail cameras -- that can be operated with batteries at remote locations storing video, infrared night video, and photos on memory cards have opened up a significant new field of collecting information for wildlife management (Hofmeester, Rowcliffe, \& Jansen, 2016). Originally developed

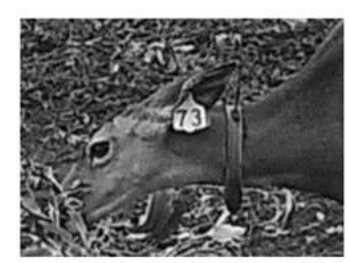

Figure 1. Tagged doe with radio collar 
primarily for hunters, efforts are underway to develop pattern recognition software that can convert images to data (Tack, West, McGowan, Ditchkoff, Reeves, Keever, \& Grand, 2016) dramatically improving the effectiveness of this tool.

The doe in Figure 1 was recently photographed in San Jose, California, where in 2007 a gated community considered using archers to reduce the deer population. Two issues that were cited in favor of this action, damage to landscaping and the risk of deer-vehicle collisions, are commonly raised across communities. The plan to use archers was abandoned after angry protests about killing the deer and public safety, also a common response to a proposed deer cull. Instead, a contractor was hired to sterilize the deer. A count of the deer was taken in January, 2013, as the sterilization process was underway showing 175 deer, 70 males and 105 tagged females. Females were tagged with identifying numbers and some were fitted with radio collars to help evaluate the progress of the project. Deer tags are sometimes pulled out. Radio collars are large and present some risk to deer survival and quality of life. They also have limited battery life, but the technology is rapidly improving.

The contractor, White Buffalo, used a distance sampling method (Horcajada-Sanchez \& Barga, 2015) in follow up surveys of the deer to monitor the population change. Volunteers at the gated community organized a physical count of the population that involved dividing the area and assigning pairs of observers to drive around in golf carts with binoculars to count the deer. It soon become clear that the volunteer count was providing a good estimate of the population and was less expensive than using a contractor. As part of this research study, a trail camera survey of the area from July, 2016 to July, 2017 verified that the volunteers were indeed doing a good job of determining the deer population. No uncounted deer were identified. To encourage public participation, a community website was created for the project where camera video and project updates are shared at www.sjdeer.com.

For San Jose, the population reduction effort was too successful. All of the community does had been sterilized and no new does were migrating in. Bucks were migrating out. Given that trend, it appeared the population was headed for eradication. The camera survey confirmed that one sterilized doe, Doe 100, had a fawn, but the doe died a few months later. The fawn survived, but turned out to be a buck, not what was needed for reproduction.

The community had agreed on a target of 70 to 90 deer. Most communities want some deer, perhaps just fewer deer. By the fall of 2016, the population count fell below this target. Resident deer were moving in and out of the community using the large open front entrance, but the rest of the perimeter was fenced. To make it easier for deer outside the community to enter and help sustain the population, cameras were used to identify locations for openings in the fence that would safely allow outside, untagged does to enter the community. Cameras documented that tagged, resident deer routinely used two large openings made in the fence, but for months none of the untagged does from outside the community would enter, although they were seen inspecting the openings. Finally, an untagged doe came in, only to be chased out several times by one of the tagged resident does defending her territory.

\section{A WEBSITE TO PROVIDE INFORMATION FOR KEY DECISION ISSUES}

Involvement in the San Jose case was an outcome of a project started in 2010 to collect information about suburban deer management and organize it on a website so that community decision makers could easily share and find information. Information for the website is collected from a daily internet search (Webb, 2016) using about 60 related keywords and Google Alerts, a tool that delivers search information at specified time periods on keywords. A Bing search is also conducted to increase the chances of finding relevant information. Key information from each source, mostly news articles, is saved on the relevant web page subject to copyright restrictions. Several Google Scholar searches are also running using Google Alerts so new research is typically discovered as it becomes available online. The site map in Figure 2 for www.deerfriendly.com/deer-population-control has been developed based on news accounts of issues that are raised in the public debate.

The top web page in the site hierarchy provides some summary information for key decision issues, gray boxes in Figure 2, discovered to be a significant based on an examination of the news reports and research. Links are provided to sub-pages where detailed information on each topic is collected. In addition to providing a knowledge base for decision makers, the collected information provides a basis for creating rules in the simulation model that is designed 
to let decision makers evaluate the implications of different policies such as the population impact and cost of nonlethal and lethal population control methods.

Email exchanges with community members from across the country involved in pubic management of their local deer provide encouragement that the website has been useful as a source of information. From page creation in June, 2011, to April, 2017, the top page was viewed over 29,000 times by about 25,000 users.

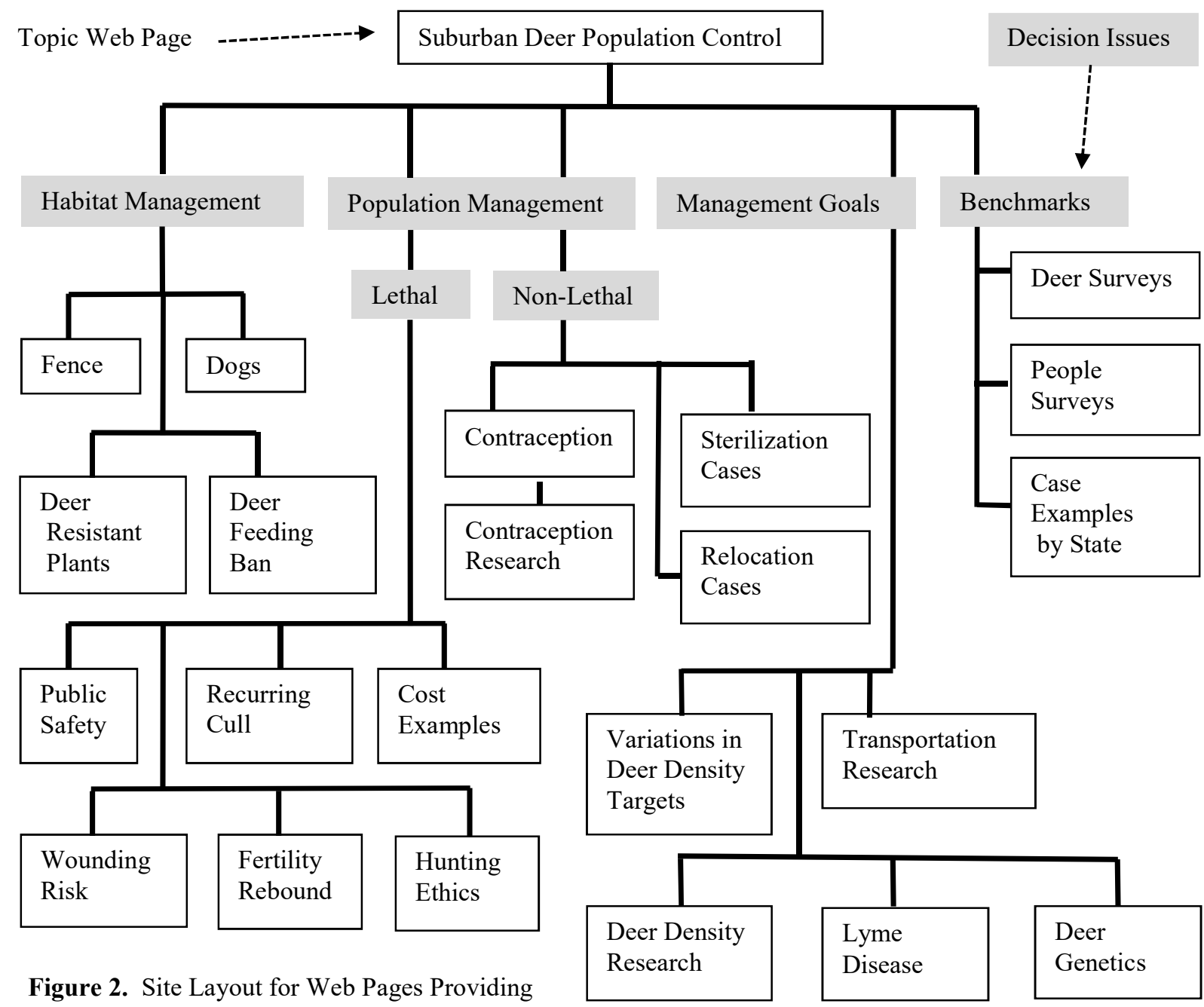
Information on Key Issues

(White Background Boxes are Web Pages, Gray Boxes are Links to Pages by Topic)

\section{REVIEW OF RESEARCH ON SUBURBAN DEER MANAGEMENT DECISION SUPPORT AND SIMULATION}

With the recovery of white-tail deer populations and the development of suburbs in the latter half of the twentieth century, there was increased interest in managing suburban deer. Some computer based decision support systems have been developed and empirical analysis has been conducted to provide insight into management issues. For example, a decision support system called "Suburban Deer Population Model" developed in the late 1990's and updated as recently as March, 2017, is available at on the internet for download at the Clearing House for Ecology 
Software (Etter \& Van Deelen, 2004). The model was developed and runs using Stella 5.0 software for Windows computers but can be run on Macintosh computers also. The model has three required inputs: removals by sex, initial population size, and size of management area. Optional inputs include the sex ratio, recruitment (birth rate), and mortality rates. The default value for the sex ratio is set at 60:40 females to males, based on suburban culling and management experience.

Data used to estimate other inputs such as survival and movement information came from 147 radio-collared whitetailed deer taken from a single, geographical sample where mortality and migration characteristics were somewhat unique, very different from the San Jose case. Some relationships are deer density dependent, but there is little demographic detail. Research related to model development includes a 2002 paper from Etter, Karmen, Van Deelen, Ludwig, Chelsvig, Anchor, and Warner documenting 10 logistic models related to suburban doe survival. Data for dispersal rates (migration) were also included in this paper. During the spring dispersal rates were $7 \%$ for does, $6 \%$ for fawns, and $50 \%$ for bucks with all but one (buck) staying within $9 \mathrm{~km}$ (page 1). An earlier proceedings (Etter, Van Deelen, Ludwig, Hollis, Chelsvig, \& Warner, 2000, p. 198) shows little dispersal for does and $20 \%$ for adult bucks. Birth rates were inversely related to deer density - does produce more fawns when deer density is low compared to the available food supply. The empirical estimate from this proceedings (Etter, Van Deelen, Ludwig, Hollis, Chelsvig, \& Warner, 2000, p. 200) was included with other cited research to obtain the birth rate equation for the model developed in this paper.

Rondeau and Conrad (2003) generate an equation system using data from a study of the Irondequoit, New York, deer population. They rely on a single equation to estimate population, create an equation to estimate deer mortality as a result of deer/vehicle collisions, and include a variety of cost estimates related to deer damage such as to vehicles and vegetation. The decision recommendation resulting from a very sophisticated mathematical analysis of these underlying equations was: "the optimal management ... dictates that authorities harvest as many animals as safety constraints will allow, when the stock exceeds and endogenously determined threshold." They concluded that trying to maintain a stable population would be more expensive. The model does not consider non-lethal alternatives which the authors suspect are more expensive, but may be considered for ethical reasons (p. 280).

Also using data from Irondequoit, researchers Porter, Underwood, and Woodward (2004) created a simulation model that examined the culling or contraceptive rate required to maintain deer populations which include density dependent dispersal and recruitment rate estimates. The authors conclude that dispersal is important when managers attempt to maintain low deer density levels, but less important when target deer populations are higher. They also conclude that the data show that local management of deer populations is feasible given observed dispersal rates, but that managers should be wary of "the standard assumption that emigration equals immigration" (Porter, Underwood, and Woodward, 2004, p. 255).

A 2004 suburban deer simulation model (Kilpatrick, H.J., LaBonte, A.M., Barclay, J.S., \& Warner, G.) focuses on the use of bow hunting to control populations, generally ignores density dependence, but provides some useful data from Greenwich, Connecticut. All of these models are built on an isolated, geographical samples with sparse demographic detail. The simulation model described here attempts to combine all research cited in this paper.

\section{The Deer Density Birth Rate Relationship}

Deer have adapted to dramatic changes in food availability caused by factors such as weather, snow and drought. In order to rapidly repopulate when conditions improve, birth rates increase when there is good food availability but decrease when food is scarce. This produces what is commonly called the "rebound effect" in hunted deer. A reduction in the deer density makes more food available for surviving deer, increasing the birth rate. The birth rate equation used in the simulation model attempts to summarize results from the studies identified in this paper, expressed as a percent of carrying capacity " $K$ ", the maximum sustainable population. A 1985 study by Richter \& Labisky reports that "incidence of twinning was $38 \%$ on hunted sites and $14 \%$ on non-hunted sites" (p. 964). Verme (1969, p. 881) reports "Productivity of low-diet yearlings and prime-age animals amounted to 0.62 and 1.36 fawns per doe, respectively, compared to rates of 1.63 and 1.80 for high-diet deer." Rondeau and Conrad (2003,p. 269) take a similar approach to provide a more general population estimate using carrying capacity, $\mathrm{K}$, to estimate the annual change in the deer population: $\mathrm{F}(\mathrm{X})=0.5703 \mathrm{X}(1-\mathrm{X} / \mathrm{K})$ based on the Irondequoit, New York, deer population, $\mathrm{X}$. 
Another adaption to variability of food availability is the tendency to produce more female fawns when food is abundant and the habitat can support more deer, but to produce more male fawns when food is scarce. A 1969 study by Verme (1969, p. 881) observes that "Males comprised 70 percent of the births from physically mature mothers on low diet when bred, whereas males constituted 46.7 percent of the offspring conceived by does on high diet." The 2004 study by Porter, Underwood and Woodward (p. 252) provides an estimate of the number of female fawns produced by does at different levels of the population size as a ratio to $\mathrm{K}$, carrying capacity. However, in their analysis the carrying capacity was set at $20 \mathrm{deer} / \mathrm{km} 2$ (p. 250), quite a low number for the biological carrying capacity of a suburban environment. They report that an adult female produced on average about 0.57 female fawns per year when deer were at carrying capacity and about 0.80 per year when at 48 percent of capacity.

Table 1 reports the results for two equations related to $\mathrm{K}$, carrying capacity, for birth rate and proportion of male fawns. The equations were estimated using data from cited studies including those summarized in Table 2 . The two equations provided the best fit of alternatives including Quadratic, Cubic, Compound, Growth, Exponential, and Logistic. Since the data for K, the carrying capacity, was often provided in subjective terms -- such as high, medium, or low - the numerical value of $\mathrm{K}$ was often subjectively estimated. As a result, tests of significance are not rigorous. These equations are included as defaults in the simulation model.

Table 1. Birth Rate on Proportion of Male Fawns Equations for the Simulation Model Independent Variable: Proportion of Carrying Capacity, K

\begin{tabular}{|l|l|l|l|l|l|l|l|}
\hline Dependent Variable & Constant & Parameter $(s)$ & $F$ & R-Square & Significance & $N$ & Maximum \\
\hline $\begin{array}{l}\text { Births, Does per Fawn } \\
\text { (Logistic) }\end{array}$ & 0.026 & 108.240 & 265 & 0.96 & 0.000 & 13 & 2.1 \\
\hline $\begin{array}{l}\text { Proportion of Male } \\
\text { Fawns (Cubic) }\end{array}$ & 0.446 & $\begin{array}{l}\mathrm{b}_{1}=0.222 \\
\mathrm{~b}_{2}=-0.448 \\
\mathrm{~b}_{3}=0.365\end{array}$ & 236 & 0.987 & 0.000 & 13 & $70 \%$ \\
\hline
\end{tabular}

* The data is not a random sample, but has been taken from academic and other research reports. The value of the independent variable was subjectively estimated in most cases based on statements such as high or low population compared to carrying capacity. A maximum value for the births variable is a requirement of the Logistic model. For the Cubic model estimating the proportion of male fawns, a maximum value was set in the simulation model at $70 \%$ since this is the highest value reported in the literature. The cubic model would push this number higher at high levels of $\mathrm{K}$.

\section{Mortality}

The following mortality relationships are provided as defaults in the simulation model. Etter, Van Deelen, Ludwig, Hollis, Chelsvig, and Warner, (2000, p.202) reports on the significance of age-specific reproduction and survival with deer in good suburban environments typically not lasting beyond 10 years. Delgiudice, Fieberg, and Sampson (2006, p. 1556) observed a U shaped survival pattern in a 13 year survival study of female white-tailed deer, having high mortality rate at the beginning - fawn survival — and highly increasing rates in older deer.

\section{Migration (Dispersal)}

Dispersal of deer, or migration, provides a mechanism for maintaining genetic diversity in deer populations. Populations hindered by lack of migratory corridors are likely to suffer from genetic drift. As with birth rates, dispersal rates are density dependent and also related to habitat quality. Kilpatrick, Spohr, and Lima (2001, p. 949) report that "Annual home range size during high deer densities ( 88 to 91 deer $/ \mathrm{km} 2$ ) were larger than during periods of moderate (20 deer $/ \mathrm{km} 2)$ and low deer densities (11 deer $/ \mathrm{km} 2)$." Example sources of data for migration that are provided for user input into the simulation model appear in Table 2. Since migration is very geographically dependent, the model uses an average default rate but users are provided with examples to help adjust the model which is illustrated in Figure 3. 


\section{INTERACTIVE WEB-BASED SUBURBAN DEER MANAGEMENT SIMULATION MODEL}

Table 2. Inputs, Data, and Relationships for the Deer Simulation Model

\begin{tabular}{|c|c|}
\hline Model Inputs & Description and representative data sources \\
\hline $\begin{array}{c}\text { Maximum } \\
\text { Deer Capacity }\end{array}$ & $\begin{array}{l}\text { Number of deer. Known as "K", the biological carrying capacity can be over } 100 \text { deer per } \\
\text { square mile in suburbs (Lien, 2000, p. 1). In San Jose, the herd was } 93 \text { per square mile. }\end{array}$ \\
\hline $\begin{array}{l}\text { Suburban } \\
\text { Area }\end{array}$ & $\begin{array}{c}\text { In square miles, used to standardize some density equations and to establish constraints on some } \\
\text { variable inputs. }\end{array}$ \\
\hline $\begin{array}{l}\text { Current Deer } \\
\text { Population }\end{array}$ & $\begin{array}{l}\text { Number of bucks, does, and fawns aged less than one year. As a default, the adult buck to doe } \\
\text { ratio in a suburban environment is about } 40 \text { to } 60 \text {. (DeNicola, Etter, \& Almendinger, 2008, p. 1) }\end{array}$ \\
\hline Births & $\begin{array}{l}\text { The default equation is driven by deer density, expressed as a percent of deer capacity, using an } \\
\text { equation summarizing results from the studies cited in the previous section on recruitment and } \\
\text { these additional sources. Results of the equation can be easily scaled for each age of the doe. } \\
\text { Examples: "an average of } 0.69-1.08 \text { offspring per year" (Rutberg, 2004, p. 246), "increased } \\
\text { significantly from } 1.33 \text { to } 1.85 \text { fawns per female" as population density declined (Nielson, } \\
\text { Porter, \& Underwood, } 1997, \text { p. } 472 \text { ), "Mean fawn recruitment rate was } 0.88 \text { fawns per doe" at } \\
\text { high population density (Kilpatrick, LaBonte, Barclay, \& Warner, 2004, p. 1181). In a high } \\
\text { density deer population of Cayuga Heights, New York, 1.038 fawns per doe (Curtis, Boldgiv, } \\
\text { Mattison, \& Boulanger, 2009, p. 121) }\end{array}$ \\
\hline $\begin{array}{l}\text { Mortality } \\
\text { (Natural) }\end{array}$ & $\begin{array}{l}\text { Percentage of bucks, does, and fawns dying from natural causes each period. Includes vehicle } \\
\text { collisions, disease, predation. Natural mortality is commonly expected to increase with deer } \\
\text { density. Examples: Annual survival rate of } 64 \text { percent (Porter, Underwood, \& Woodard, 2004, } \\
\text { p. 247) so } 36 \text { percent annual mortality - high due to significant vehicle collisions. Average } \\
\text { mortality rate of about } 15 \% \text { for adult deer and about } 72 \% \text { for fawns, a high fawn mortality } \\
\text { (Nielsen, Porter \& Underwood, 1997, p. } 473 \text { ). Annual adult survival rate of above } 80 \text { percent } \\
\text { (Etter, Van Deelen, Ludwig, Hollis, Chelsvig, \& Warner, 2000, p. 200), so mortality of about } \\
20 \% \text {. }\end{array}$ \\
\hline $\begin{array}{l}\text { Migration } \\
\text { (dispersal) }\end{array}$ & $\begin{array}{l}\text { Migration rates in and out of the area for bucks, does and their fawns. Default values for } \\
\text { quarterly dispersal rates are based on the data discussed previously. Data can also be entered to } \\
\text { reflect local conditions. For example, dispersal rates are lower when food is abundant and deer } \\
\text { have no incentive to search. }\end{array}$ \\
\hline Cull Mortality & $\begin{array}{l}\text { For population strategies relying on lethal methods, the deer cull, the percentage of bucks, does, } \\
\text { and fawns killed in the cull can be entered as a percentage. }\end{array}$ \\
\hline Cull Cost & $\begin{array}{l}\text { Representative costs for sharpshooters and other lethal management methods are provided } \\
\text { based on information stored on the website from case examples reported in news media. }\end{array}$ \\
\hline $\begin{array}{l}\text { Sterilization } \\
\text { Percent }\end{array}$ & $\begin{array}{l}\text { Alternative values for the number of does sterilized can be entered. Sterilization is nearly } 100 \\
\text { percent effective and permanent. In practice a small percentage does may become pregnant or } \\
\text { die from surgery. }\end{array}$ \\
\hline $\begin{array}{l}\text { Sterilization } \\
\text { Cost }\end{array}$ & $\begin{array}{l}\text { Representative costs for doe sterilization are provided based on information stored in the } \\
\text { website from case examples reported in news media. }\end{array}$ \\
\hline $\begin{array}{l}\text { Contraception } \\
\text { Percent }\end{array}$ & $\begin{array}{l}\text { Alternative numbers for the number of does receiving contraception can be entered. } \\
\text { Contraception effectiveness is currently around } 90 \text { to } 95 \text { percent, reported up to } 100 \% \\
\text { (Hernandez, Locke, Cook, Harveson, Davis, Lopez, ... Fraker, 2006, p. 1431) }\end{array}$ \\
\hline $\begin{array}{l}\text { Contraception } \\
\text { Duration }\end{array}$ & $\begin{array}{l}\text { The effectiveness of contraceptive drugs varies from } 1 \text { to about } 6 \text { years, with longer lasting } \\
\text { drugs being more expensive. The } 6 \text { year version, SpayVac, is currently difficult to acquire. } \\
\text { Repeated use of contraceptives on the same deer may be difficult since capture is often required } \\
\text { and deer learn to evade capture. }\end{array}$ \\
\hline $\begin{array}{l}\text { Contraception } \\
\text { Cost }\end{array}$ & $\begin{array}{l}\text { Representative costs for contraceptives are provided based on information stored in the website } \\
\text { from case examples reported in news media and academic research. }\end{array}$ \\
\hline $\begin{array}{l}\text { Relocation } \\
\text { Percent }\end{array}$ & $\begin{array}{l}\text { Alternative values for the number of bucks and does that are relocated out of the area can be } \\
\text { entered. Survival rates and effectiveness of relocation vary widely based on experience and } \\
\text { local conditions. }\end{array}$ \\
\hline $\begin{array}{l}\text { Relocation } \\
\text { Cost }\end{array}$ & $\begin{array}{l}\text { Representative costs for relocation are provided based on information stored in the website from } \\
\text { case examples reported in news media. }\end{array}$ \\
\hline
\end{tabular}




\begin{tabular}{|c|c|}
\hline Model Inputs & Model Calculations \\
\hline $\begin{array}{l}\text { values) } \\
\text { Initial Conditions Variable } \\
\text { List } \\
\mathrm{K}, \text { Carrying Capacity } \\
\text { Area }\end{array}$ & $\begin{array}{l}\text { Births } \\
\text { Density dependent equations for } \\
\text { births per doe and the percent of } \\
\text { males born estimated from reported } \\
\text { research. }\end{array}$ \\
\hline Deer & \\
\hline $\begin{array}{l}\text { Bucks } \\
\text { Fertile Does }\end{array}$ & $+\downarrow$ \\
\hline Sterilized Does & Population $(t+1)=$ Population $(t)+$ \\
\hline Contracepted Does & Births $(t)-$ Mortality $(t)+$ Net Migration $(t)$ \\
\hline $\begin{array}{l}\text { Fawns }<1 \text { year } \\
\text { Male }\end{array}$ & $\begin{array}{l}\text { Fawns }<1 \text { year } \\
\text { Male }\end{array}$ \\
\hline Female & $\begin{array}{l}\text { Female } \\
\text { Age distribution tables by quarter }\end{array}$ \\
\hline $\begin{array}{l}\text { Births } \\
\text { Equations for births per } \\
\text { doe can be scaled by } \\
\text { user for each age } \\
\text { group. }\end{array}$ & $\begin{array}{l}\text { for each year from } 1 \text { to } 11 \text { years of age. } \\
\text { Bucks } \\
\text { Fertile Does } \\
\text { Sterilized Does } \\
\text { Contracepted Does }\end{array}$ \\
\hline $\begin{array}{l}\text { Natural Mortality by Age } \\
\text { Bucks } \\
\text { Does }\end{array}$ & $-\downarrow 1-$ \\
\hline Fawns & $\begin{array}{l}\text { Mortality } \\
\text { (density dependent for values above K) }\end{array}$ \\
\hline $\begin{array}{l}\text { Migration Rates by Age } \\
\text { Does In }\end{array}$ & $\begin{array}{l}\text { Fawns }<1 \text { year } \\
\text { Male }\end{array}$ \\
\hline Fawns In & Female \\
\hline Bucks In & Age distribution tables by quarter \\
\hline Does Out & for each year from 1 to 11 years of age. \\
\hline Fawns Out & Bucks \\
\hline Bucks Out & $\begin{array}{l}\text { Fertile Does } \\
\text { Sterilized Does }\end{array}$ \\
\hline $\begin{array}{l}\text { Management Cost per Deer } \\
\text { Cull, (extermination) } \\
\text { Sterilization }\end{array}$ & Contracepted Does \\
\hline $\begin{array}{l}\text { Contraception } \\
\text { Input Variables that }\end{array}$ & $\begin{array}{l}\text { Migration } \\
\text { (density dependence under investigation) } \\
\text { Fawns }<1 \text { year }\end{array}$ \\
\hline $\begin{array}{l}\text { Change Over Time } \\
\text { Deer Cull Mortality }\end{array}$ & $\begin{array}{l}\text { Male } \\
\text { Female }\end{array}$ \\
\hline $\begin{array}{l}\text { Deer Cull Mortality } \\
\text { Bucks }\end{array}$ & Age distribution tables by quarter \\
\hline Does & for each year from 1 to 11 years of age \\
\hline Fawn & $\begin{array}{l}\text { for migration in and migration out. } \\
\text { Bucks }\end{array}$ \\
\hline Does Sterilized & Fertile Does \\
\hline $\begin{array}{l}\text { Does Contracepted } \\
\text { Contraception Duration }\end{array}$ & $\begin{array}{l}\text { Sterilized Does } \\
\text { Contracepted Does }\end{array}$ \\
\hline
\end{tabular}

Figure 3. Flow Diagram for Suburban Deer Population Management Simulation 
In order to provide a sense of the impact and cost of alternative deer management strategies, a simulation model was constructed using data from sources as described in this paper. A list of inputs that a user can set for the model, formulas in the model, and default values for many inputs are provided along with sources in cited in this paper. The model and available inputs continue to be updated based on the ongoing search for information.

The model runs online in Google sheets and is embedded in a Google site for easy access. The primary analytical differences of this model compared to previous efforts is the very detailed demographic analysis. Also, the model allows users to enter local data or choose from example data and to easily modify equations. Example data is provided to help users with this task. Results of the model are compared with the many actual case examples obtained through the search process, so the model undergoes continuous improvement as new data becomes available. Among the many case examples examined in constructing the simulation, one seems particularly surprising.

\section{The Cornell Anomaly}

The result of a sterilization project at Cornell in New York received considerable public attention in a Washington Post article titled: "Trying to limit the number of deer, with surprising results" (Landers, 2014). The lead biologist on the project summarizes that: "I thought that sterilization in an open population where things can move in and out won't work. Maybe it was worth doing it in a sophisticated way to say we tried in the best possible way and it didn't make a difference." According to the article, although the number of does and fawns was reduced, an offsetting increase in the buck population resulted in no reduction of the total population. Bucks were drawn there by the sterilized does that continued to go into heat, attracting bucks as part of the breeding process.

The published study reported "a $38 \%$ and $79 \%$ decrease of total adult females and fawns visible in sampled photographs, respectively, and an $873 \%$ increase in adult male visitation to camera traps" (Boulanger \& Curtis, 2016, p. 727). The data for sampled photographs include repeat visits of the same deer. Male visitations in the first year were only $4 \%$ of the total, for a buck to doe ratio of about one to eight. The sex of fawns and many deer in the photographs could not be determined. In a suburban herd the buck to doe ratio is typically about two to three. The $873 \%$ increase was just enough to bring the buck to doe ratio back to its normal level. There is no explanation in the paper for the incredibly low starting number of bucks. Although the paper concludes that the experiment failed because the population remained approximately the same, the number of deer seen in sampled photographs actually decreased by $32 \%$ (Boulanger \& Curtis, 2016, p 732).

The conclusion that the deer population was not reduced by the experiment is based on analysis of the photographic data using the software NOREMARK (White, 1996). While no population estimates were provided for adult males, the population estimates for adult females show an increase over the study (Boulanger \& Curtis, 2016, p 732), in contrast to the $38 \%$ decrease in total females from sampled photographs. Total population estimates later presented by the researchers appear to show that the total population trend was about the same but a little higher than the female population based on the software estimate, suggesting little effect from adult males on the total population trend estimate (Boulanger \& Curtis, 2017). There is a dramatic difference in the population trends based on the photographic data and the software interpretation, yet both results are used to selectively draw conclusions.

An important technical issue left out of the Washington Post article is that two sterilization methods were used, ovariectomy and tubal ligation, not just tubal ligation. Does having their ovaries removed, ovareictomy, typically cannot go into heat, so are not likely to attract bucks. Two other sterilization projects with publically accessible websites both report reduced deer populations: in Ohio at CliftonDeer.org (Year 2 Field Operations Report, 2016-17) and in Maryland at www.WildlifeRescueInc.org (First ever Non-Lethal White-tailed Deer Birth Control Sterilization, n.d.). The San Jose case also used both sterilization methods, although a much smaller proportion of tubal ligation, but as reported in Table 3 resulted in an 89 percent decrease in the number of bucks. These counts were made by direct observation. The authors of the Cornell study acknowledge "it is unclear why male numbers increased," "an inability to reliably estimate the male portion of the campus deer population," (Boulanger \& Curtis, 2016, p. 732) and that that their result of a dramatically increased number of bucks is "currently undocumented in the literature" (Boulanger \& Curtis, p. 733). The increase in the number of bucks photographed may also have been caused by the food piles used as bait to attract does for sterilization, by the fawns born in the area during the study, by a change in the areas frequented by a group of bucks. 
The experience of a one year camera survey in San Jose makes very clear the difficulty of counting unmarked deer. The cameras are good for counting marked deer and were used in San Jose to verify the physical count done by volunteers. Among the marked deer we found that the same deer would return frequently to the same location, but this varied over time. Getting accurate population estimates continues to be a challenge for wildlife management and is the subject of much research devoted to improving available technology and methods in an environment of tight funding. The contractor on the San Jose Project, White Buffalo, continues to experiment with population control methods, providing new data and possible alternative solutions.

\section{MODEL OUTPUT}

Figure 4 shows the output from the simulation model using data from the San Jose case example. The sterilization began in January, 2013, with some does relocated resulting in the drop in the number of does reported in Table 3 for the beginning of the project. The camera surveys indicate that the volunteer counts are extremely accurate. Images from the cameras allow for evaluation of deer behavior, provide good information about migration and births, and have been used in an effort to encourage in-migration of new does in an effort to change the current forecast that the deer population will approach zero in about five years. So far, efforts to encourage deer migration into the community by modifying fencing where there seem to be good opportunities for immigration have not been successful. Community deer continue to migrate in and out, but deer outside the community are reluctant to enter and are confronted by resident deer. The target deer population based on community consensus is illustrated by the gray area in the Figure 4. The population has already fallen below this target of 70 to 90 deer.

Table 3. San Jose Actual Deer Count and Forecast

\begin{tabular}{|l|c|c|c|}
\hline Date & Bucks & Does & Total \\
\hline 2013 Start & 70 & 105 & 175 \\
\hline 2013, Jan & 70 & 93 & 163 \\
\hline 2013, Fall & 42 & 88 & 130 \\
\hline 2014, Fall & 22 & 81 & 103 \\
\hline 2015, Spring & 23 & 63 & 86 \\
\hline 2015, Fall & 18 & 67 & 85 \\
\hline 2016, Spring & 11 & 71 & 82 \\
\hline 2016, Fall & 11 & 57 & 68 \\
\hline 2017, Spring & 8 & 51 & 59 \\
\hline Forecast & & & \\
\hline 2018, Fall & 4 & 35 & 39 \\
\hline 2019, Fall & 3 & 25 & 28 \\
\hline 2020, Fall & 2 & 15 & 17 \\
\hline 2021, Fall & 1 & 6 & 7 \\
\hline 2022, Fall & 0 & 2 & 2 \\
\hline
\end{tabular}




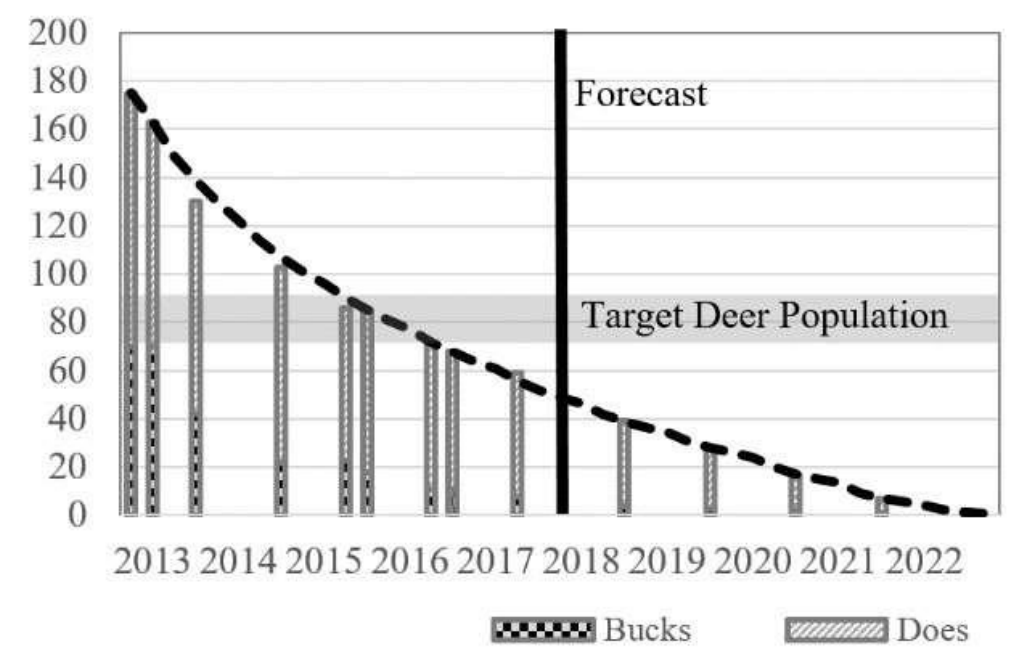

Figure 4. San Jose Deer Population Count, Forecast from Simulation, Target Population

The simulation model fits the historical data very well because the model allows for input of local data to improve model performance, not a feature easily accomplished in previous simulation attempts that were estimated using isolated geographic samples. In this case, there is very good data on starting deer demographics, created by the contractor during the sterilization process. Migration rates have been monitored closely by cameras and by many concerned volunteers that share data through the project website and also through personal contacts that enhance community social interaction.

Efforts to build the model with a few equations as used in previous simulation attempts resulted in simulation forecasts that were counter intuitive. Deer populations persisted far into the future even though a simple understanding that the deer are dying out and that they rarely live beyond 10 or 11 years suggests that the result above from the simulation model should be expected - virtually no deer after 10 years into the project. The poor forecast of a persisting population from other models is a result of limited demographic detail. In this simulation, deer populations are estimated for each age in years. The model tracks deer as they age and die.

\section{SUMMARY}

Although building the simulation model was a goal of the project from the beginning, model construction took much longer than anticipated because of the complex nature of the problem and the data collection process. Available formal simulation models appear to have played little or no role in decision making for suburban deer management, no references to these models have been discovered in the news accounts of the public debate on deer management. However, the web-based knowledge base developed to support decision making as illustrated in Figure 2 has been used by many communities to assist in their decision process.

Previous efforts at building simulation models relying on several equations estimated from a single geographic sample may not be applicable across different locations. A model following the format of several equations failed to provide a reasonable forecast for San Jose. Based on this experience, extensive detail was added to the model with demographic tables for the population, mortality, and migration. Also, the data used to estimate these previous simulations was very different from the San Jose data, particularly for mortality and migration, also making these simulations unreliable. Based on this observation, equations used in this model were estimated from a wide geographic sample and designed to be easily scaled by the user to reflect local conditions. Also, the model allows users to use default data, peruse examples of data that they can enter in the model, or enter data based on observations from their 


\section{Issues in Information Systems \\ Volume 18, Issue 2, pp. 158-170, 2017}

location. In the San Jose case, good data was available from observations on the age distribution of deer (demographics), migration, and mortality rates. The Cornell case illustrates some of the data challenges when measuring the impact of population control methods.

The simulation model developed here continues to be tested against the case data accumulated in the knowledge base and is being used to support decision making in San Jose. Although the model will be available for free use through an on-line website, preliminary testing indicates the model may appear too complex for some users to run. Work is underway on improving the user interface. Future research will involve testing acceptance of the model and using output from the model to assist with local decisions.

\section{REFERENCES}

Boulanger, J.R., \& Curtis, P.D. (2016). Efficacy of surgical sterilization for managing overabundant suburban white-tailed deer. Wildlife Society Bulleting, 40(4), 727-735.

Boulanger, J.R. \& Curtis, P.D. (2017, June). Surgical sterilization for suburban deer management: myth or reality? Paper presented at the International Urban Wildlife Conference, San Diego, California.

Curtis, P.D., Boldgiv, B., Mattison, P.M., \& Boulanger, J.R. (2009). Estimating deer abundance in suburban areas with infrared-triggered cameras. Human-Wildlife Conflicts, 3(1), 116-128.

Delgiudice, G.D., Fieberg, J.R., \& Sampson, B.A. (2006). A long-term age-specific survival analysis of female white-tailed deer. Journal of Wildlife Management, 70(6), 1556-1568.

DeNicola, A.J., Etter, D.R., \& Almendinger, T. (2008). Demographics on non-hunted white-tailed deer populations in suburban areas. Human-Wildlife Conflicts, 2(1), 102-109.

First ever non-lethal white-tailed deer birth control sterilization spaying research program (n.d.)

WildlifeRescueInc.org. Retrieved July 9, 2017, from

http://www.wildliferescueinc.org/nonlethal_deer_project.html

Horcajada-Sanchez, F., \& Barja, I. (2015). Evaluating the effectiveness of two distance-sampling techniques for monitoring roe deer (capreolus capreolus) densities. Annales Zoologici Fennici, 52(3), 167-176.

Hernandez, S.H., Locke, S.L., Cook, M.W., Harveson, L.A., Davis, D.S., Lopez, R.R., ... Fraker, M.A. (2006). Effects of SpayVac ${ }^{\circledR}$ on urban female white-tailed deer movements. Wildlife Society Bulletin, 34(5), 14301434.

Hofmeester, T. R., Rowcliffe, J. M. \& Jansen, P. A. (2016), A simple method for estimating the effective detection distance of camera traps. Remote Sensing in Ecology and Conservation. Available:

http://onlinelibrary.wiley.com/doi/10.1002/rse2.25/full

Etter, D.R., Karmen, M.H., Van Deelen, T.R., Ludwig, D.R., Chelsvig, J.E., Anchor, C.L., \& Warner, R.E. (2002). Survival and movements of white-tailed deer in suburban Chicago, Illinois. The Journal of Wildlife Management, 66(2), 500-510 
Etter, D.R., Van Deelen, T.R., Ludwig, D. R., Hollis, K. M., Chelsvig, J. E., \& Warner, R. E. (2000) Overabundant deer: Better management through research. Wildlife Damage Management Conferences -- Proceedings. Paper 29. 197-205. Available: http://digitalcommons.unl.edu/icwdm_wdmconfproc/29

Etter, D.R., Van Deelen, T.R. (2004). Suburban deer population model. Clearing House for Ecology Software. Available: http://nhsbig.inhs.uiuc.edu/wes/model_description.html

Kilpatrick, H.J., LaBonte, A.M., Barclay, J.S., \& Warner, G. (2004). Assessing strategies to improve bow hunting as an urban deer management tool. Wildlife Society Bulletin, 32(4),1177-1184

Landers, J. (2014). Trying to limit the number of deer, with surprising results. The Washington Post, September 29, 2014. Available at: https://www.washingtonpost.com/national/health-science/trying-to-limit-thenumber-of-deer-with-surprising-results/2014/09/29/3c16f9dc-28a5-11e4-958c268a320a60ce_story.html?utm_term=.634d7ad2ee81

Lien, R. (2000). Urban deer management in Wisconsin. Wisconsin Urban \& Community Forests, 8(1), 1-5.

McCance, E.C., Decker, D.J., Colturi, A.M., Baydack, R.K., Siemer, W.F., Curtis, P.D., \& Eason, T. (2017). Importance of urban wildlife management in the United States and Canada. Mammal Study, 42(1), 1-16.

Nielsen, C.K., Porter, W.F. \& Underwood, H.B. (1997). An adaptive management approach to controlling suburban deer. Wildlife Society Bulletin, 25(2), 470-477.

Porter, W.F., Underwood, H.B., \& Woodard, J.L. (2004). Movement behavior, dispersal, and the potential for localized management of deer in a suburban environment. Journal of Wildlife Management, 68(2), 247256.

Rutberg, A.T. (2013). Managing wildlife with contraception: why is it taking so long? Journal of Zoo and Wildlife Medicine, 44(4s), S38-S46.

Rutberg, A.T., Naugle, R.E., Thiele, L.A., \& Liu, I.K.M. (2004). Effects of immunocontraception on a suburban population of white-tailed deer. Biological Conservation, 116(2), 243-250.

Richter, A., \& Labisky, R. (1985). Reproductive dynamics among disjunct white-tailed deer herds in Florida. Journal of Wildlife Management, 49(4), 964-971.

Rondeau, D., \& Conrad, J.M. (2003). Managing urban deer. American Journal of Agricultural Economics, 85(1): 266-281

Tack, J.L.P., West, B.S., McGowan, C.P., Ditchkoff, S.S., Reeves, S.J., Keever, A.C., \& Grand, J.B. (2016). AnimalFinder: A semi-automated system for animal detection in time-lapse camera trap images. Ecological Informatics, 36(November), Pages 145-151

Verme, L. (1969). Reproductive patterns of white-tailed deer related to nutritional plane. The Journal of Wildlife Management, 33(4), 881-887. 
Webb, G.K. (2016). Internet search engine capture success rates and mortality statistics for hyperlinks to public news articles. Issues in Information Systems, 17(2), 25-33.

White, G.C. (1996). NOREMARK: population estimation from mark-resighting surveys. Wildlife Society Bulletin, $24,50-52$.

Year 2 Field Operations Report (2016-17). CliftonDeer.Org. Retrieved July 9, 2017, from http://cliftondeer.org/year-two-field-operations-report/ 